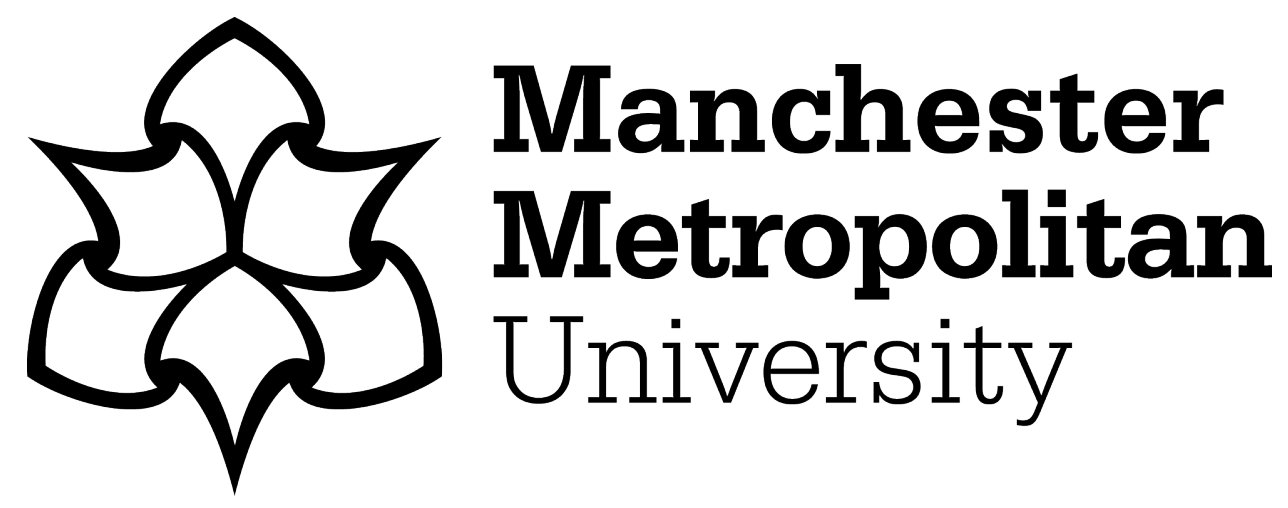

Leal Filho, W, Vargas, VR ORCID logoORCID: https://orcid.org/0000-00020008-0747, Salvia, AL, Brandli, LL, Pallant, E, Klavins, M, Ray, S, Moggi, S, Maruna, M, Conticelli, E, Ayanore, MA, Radovic, V, Gupta, B, Sen, S, Paço, A, Michalopoulou, E, Saikim, FH, Koh, HL, Frankenberger, F, Kanchanamukda, W, Cunha, DAD, Akib, NAM, Clarke, A, Wall, T and Vaccari, M (2019) The role of higher education institutions in sustainability initiatives at the local level. Journal of Cleaner Production, 233. pp. 1004-1015. ISSN 0959-6526

Downloaded from: https://e-space.mmu.ac.uk/623361/

Version: Accepted Version

Publisher: Elsevier

DOI: https://doi.org/10.1016/j.jclepro.2019.06.059

Usage rights: Creative Commons: Attribution-Noncommercial-No Derivative Works 4.0

Please cite the published version 


\title{
The Role of Higher Education Institutions in Sustainability Initiatives at the Local Level
}

\author{
Journal of Cleaner Production 233:1004-1015 01 Oct 2019 DOI \\ https://www.sciencedirect.com/science/article/pii/S0959652619320128?via\%3Dihub
}

Walter Leal Filho', Valeria Ruiz Vargas ${ }^{2}$, Amanda Lange Salvia ${ }^{3 *}$, Luciana Londero Brandli ${ }^{4}$, Eric Pallant $^{5}$, Maris Klavins ${ }^{6}$, Subhasis Ray ${ }^{7}$, Sara Moggi ${ }^{8}$, Marija Maruna ${ }^{9}$, Elisa Conticellii ${ }^{10}$, Martin Amogre Ayanore ${ }^{11}$, Vesela Radovic ${ }^{12}$, Bhumika Gupta ${ }^{13}$, Salil Sen ${ }^{14}$, Arminda Paço ${ }^{15}$, Eleni Michalopoulou $^{16}$, Fiffy Hanisdah Saikim ${ }^{17}$, Hock Lye Koh $^{18}$, Fernanda Frankenberger ${ }^{19}$, Wasan Kanchanamukda ${ }^{20}$, Dênis Cunha ${ }^{21}$, Noor Adelyna Mohammed Akib ${ }^{22}$, Amelia Clarke ${ }^{23}$, Tony Wall ${ }^{24}$ and Mentore Vaccari ${ }^{25}$

1. European School of Sustainability Science and Research, Hamburg University of Applied Sciences, Faculty of Life Sciences, Ulmenliet 20D-21033 Hamburg, Germany \& Manchester Metropolitan University, School of Science and the Environment, Chester Street, Manchester M1 5GD, UK. E-mail: walter.leal2@haw-hamburg.de

2. Manchester Metropolitan University, School of Science and the Environment, Chester Street, Manchester M1 5GD, UK. E-mail: v.vargas@mmu.ac.uk

3. University of Passo Fundo, Graduate Program in Civil and Environmental Engineering, BR 285, Passo Fundo/RS, Brazil. E-mail: amandasalvia@gmail.com

4. University of Passo Fundo, Graduate Program in Civil and Environmental Engineering, BR 285, Passo Fundo/RS, Brazil. E-mail: brandli@upf.br

5. Allegheny College, Department of Environmental Science \& Studies, 520 North Main St., Box E, Meadville, PA, USA. E-mail: epallant@allegheny.edu

6. University of Latvia, Department of Environmental Science, Raina Blvd. 19, Riga, LV-1586, Latvia. E-mail: maris.klavins@lu.lv

7. Xavier Institute of Management Bhubaneswar, Odisha, India. E-mail: sray@ximb.ac.in

8. University of Verona, Department of Business Administration, Via Cantarane, 24, 37129 Verona. Italy. E-mail: Sara.moggi@univr.it

9. University of Belgrade, Department for Urbanism, Serbia. E-mail: m.ma@sezampro.rs

10. Department of Architecture (DA), University of Bologna, V.le Risorgimento 2, Bologna, 40135, Italy. E-mail: elisa.conticelli@unibo.it

11. Department of Family and Community Health, School of Public Health, University of Health and Allied Sciences, Ho, Volta Region, Ghana. E-mail: mayanore@uhas.edu.gh

12. Institute for Multidisciplinary Research, University of Belgrade, Kneza Višeslava 1, 11030 Belgrade, Serbia. Email: vesela.radovic@imsi.rs

13. Institut Mines-Télécom Business School (Management, Marketing and Strategy Department), 9 Rue Charles Fourier Evry 91011, France, E-mail: bhumika.gupta@telecom-em.eu

14. Institut Mines-Télécom Business School (Management, Marketing and Strategy Department), 9 Rue Charles Fourier Evry 91011, France, E-mail: salil.sen@gmail.com

15. University of Beira Interior, Department of Management and Economics, Research Unit NECE, Estrada do Sineiro, 6200-209, Covilhã, Portugal. E-mail: apaco@ubi.pt

16. School of Chemistry, University of Bristol, Bristol, United Kingdom. E-mail: em15151@bristol.ac.uk

17. Universiti Malaysia Sabah, Institute for Tropical Biology and Conservation, Kota Kinabalu, Malaysia. E-mail: fiffy@ums.edu.my

18. Jeffrey Sachs Center on Sustainable Development, Sunway University, Bandar Sunway, 47500 Selangor, Malaysia. E-mail: hocklyek@sunway.edu.my

19. Pontifical Catholic University of Paraná (PUCPR) and Positivo University (UP), Business School, Curitiba, Brazil. E-mail: ferfrank1@,hotmail.com

20. Thaksin University International College, Thaksin University, Songkhla, Thailand. E-mail: granjanamukda@hotmail.com

21. Universidade Federal de Viçosa, Departamento de Economia Rural, Avenida Purdue s/n , Campus Universitário, CEP 36570-900 Viçosa/MG, Brazil. E-mail: denis.cunha@ufv.br

22. Universiti Sains Malaysia, Centre for Global Sustainability Studies (CGSS), Penang, Malaysia. E-mail: adelyna@usm.my

23. Centre for Environment and Business, School of Environment, Enterprise and Development (SEED), University of Waterloo, Room 4229, Environment 3 Building, 200 University Ave. West, Waterloo, Ontario, Canada N2L 3G1. E-mail: amelia.clarke@uwaterloo.ca

24. Centre for Work Related Studies, University of Chester, Chester CH1 4BJ, United Kingdom. E-mail: t.wall@chester.ac.uk 
25. Research laboratory for Appropriate Technologies for Environmental Management in Resource-limited Countries (CeTAmb Lab), Department of Civil, Environmental, Architectural Engineering and Mathematics, University of Brescia, Brescia, Italy. E-mail: mentore.vaccari@unibs.it

*corresponding author

Wordcount: 7,833

\title{
The Role of Higher Education Institutions in Sustainability Initiatives at the Local Level
}

\begin{abstract}
Universities are central players and important economic actors in many regions, and many of them are, in general, nationally and internationally active in respect of matters related to sustainable development. But there is a paucity of research which examines their contributions towards sustainability efforts at the local level, i.e. in the places they are situated. This paper addresses this need, by reporting on a qualitative study deploying a Matrix, which allows an analysis and reporting of regional sustainable development initiatives of a set of 22 universities in industrialised and developing countries. Recommendations to enhance their role are provided, including the importance of pursuing partnerships and joint initiatives, understanding the need of local communities, and making their know-how more widely available. The scientific value of this research is related to the understanding of how the interaction between universities and local communities happens and by shedding light to this topic, it supports universities to improve their own actions. Its implications are two-fold: it demonstrates the potential of universities as local players, and outlines the range of activities they may engage with, and which may allow them to act as pillars to local sustainability initiatives.
\end{abstract}

Keywords: sustainability - higher education - local initiatives - engagement

\section{Introduction}

Higher education institutions (HEIs) around the world have been incorporating sustainable development (SD) into their systems, curricula, and local communities for more than thirty years (Leal Filho et al. 2017a; Lozano et al., 2013a; Boks and Diehl, 2006; Wemmenhove and de Groot, 2001). In the last decade, the United Nations Educational, Scientific, and Cultural Organization (UNESCO) has helped coordinate Education for Sustainable Development (ESD) (UNESCO, 2014) through the Higher Education Sustainability Initiative (HESI). The objective of UNESCO's initiative is to provide a platform for colleges and universities to engage with the United Nations Sustainable Development Goals (UN SDGs) and over 300 institutions have now joined UNESCO's efforts (https://sustainabledevelopment.un.org/sdinaction/hesi). Of the UN SDGs, education was identified as a stand-alone goal (SDG 4), and many of the targets for that goal require universities to act, while others relate directly to learning and teaching (SDSN Australia/Pacific 2017).

Higher Education Institutions have the societal responsibility of providing guidance to students, faculty, staff, and administration (Viebahn, 2002; Bantanur et al., 2015), and their decisions affect the economic, social and environmental dimensions of the communities and regions around them (Katiliute et al., 2014). Universities have been considered significant contributors to the promotion of sustainability and the pursuit of regional sustainability (Karatzoglou, 2013). The level of integration of sustainability can range from formulations of policy statements, integration into curricula, green campus activities, and signing on international charters or declarations (Lozano et al. 2013b; Sammalisto and Lindhqvist, 2008). 
The literature on education for sustainable development (ESD) emphasizes the need to teach students to examine relevant information, to think critically, to cultivate flexible and adaptive practices, and expose them to applied experimentation (Wiek et al. 2011). Ensign (2017) states, "The various dimensions of sustainability in higher education were explored in the Handbook of Theory and Practice of Sustainability in Higher Education and new ideas are emerging for best practices for teaching university students to contribute to making solutions for the UN SDGs" (Leal Filho, 2017b; Pallant et al. in press). Ensign (2017) argues that universities and colleges are responsible for producing students with both traditional degrees, but also the ability to act as agents of change throughout the world. Universities must prepare students "to apply their knowledge to solve unprecedented problems" (Ensign 2017). University graduates will enter society as part of "the energetic society" that is required to ensure that sustainable development goals become reality (Hajer et al. 2015).

A wide range of stakeholders is required to address challenges related to sustainable development (WCED, 1987; United Nations, 2016). Regional initiatives and transition paths are crucial for global progress towards sustainable development (Radinger-Peer and Pflitsch, 2017). The importance of the involvement of universities within their local and regional communities in terms of SD has been highlighted in national and international policy frameworks (Zilahy and Huisingh, 2009). Universities have been encouraged by the Copernicus Charter signed by about 300 higher education institutions based in Europe, to actively develop community engagement work towards sustainable development (CRECopernicus, 1994).

\section{Review of the Literature on Higher Education and Sustainability Initiatives}

Historically, some universities have been used as a political instruments to shape economic development (Peer \& Penker, 2016). In some cases, higher education institutions have been explicitly created to accelerate regional economic and social development (Peer \& Penker, 2016). This role has especially been successful in terms of the regional labour market and regional economy (Peer \& Penker, 2016). Due to their size and influence, large public universities tend to have more impact on sustainable development initiatives within their regions than their smaller counterparts. (Mosier, 2015). There is also evidence of growing expectations for the engagement of universities in the deliberation and support of decisionmaking processes (Breznitz \& Feldman, 2012).

Over time the role of universities has shifted from passive knowledge creation toward a more proactive and engaged role within their regions (Peer \& Penker, 2016). Also, the economic focus of universities' role regionally has been changing to include social, cultural and ecological foci as universities collaborate with industry and government, i.e. Triple Helix(Gunasekara, 2006a; Gunasekara, 2006b; Zilahy \& Huisingh, 2009; United Nations, 2016). The interaction of governments and universities in local and regional initiatives for sustainable development deserves further investigation: some efforts have been uncoordinated (Sedlacek, 2013), but the full nature of engagement has only recently come under academic investigation (MacDonald et al., 2018; Peer \& Penker, 2016, Zilahy and Huisingh, 2009).

Increasingly, universities are developing internationalisation strategies. This international focus can provide an opportunity for universities to bring international practices in sustainability back to the local level (Soliman et al., 2018). Lozano et al. (2015) include the following activities in outreach linked to sustainable development: exchange programmes, joint degrees with other universities, joint research, partnerships with external organisations, events open to the community.

Universities influence local communities by serving as models for sustainability and by providing socio-economic contributions to their host communities through the graduates that 
are employed in the local region or creating living laboratories in cooperation with stakeholders within their communities (Peer \& Penker, 2016, Disterheft et al., 2012, Evans et al., 2015). In this respect, Moon et al. (2018) mentions the case of universities that contribute to the SDGs through partnerships with local businesses. Usually, the level of development of these partnerships is rather low and mostly uses courses as approach, but it is not applied in an integrative way in HEIs operations. In this sense, the usefulness of these partnerships is rather limited for both national and regional initiatives and especially for professional training (Moon et al., 2018). The SDGs have a multidisciplinary approach which also contributes to address interconnected problems, which also demand interconnected governance responses (Stevens \& Kanie, 2016). Local partnerships are a prime way to tackle this issue.

A critical success factor for regional sustainability initiatives is multidisciplinarity (Zimm et al., 2018, Zilahy \& Huisingh 2009; Radinger-Peer \& Pflitsch, 2017, Santos \& Horta, 2018, Elliott et al., 2018). However, education for sustainable development skills and knowledge are rarely embedded fully in universities' curricula (Cebrián, 2017, Velazquez et al., 2005). Moreover, capacity building led by universities to enhance sustainable development within local communities is ad hoc, often lacks evaluation and is not centrally co-ordinated by universities but often lies within individual efforts (Shiel et al, 2016). Yet, community engagement could act as a tool for teaching and learning if well included in a new curricular approach, resulting in students becoming more engaged in sustainability actions (James \& Schmitz, 2011).

The capacity of universities to take a leading role in regional sustainable development is an under investigated area in the literature (Blume, et al., 2017, Horlings \& Padt, 2013), and there is not a clear understanding of the best methods for maintaining equitable transfer of knowledge between universities and their local communities (Peer \& Stoeglehner, 2013). More studies in this area are needed, especially concerning how to assess the impacts of university contribution outside its borders. According to Findler et al. (2019), indicators from sustainability assessment tools, which help universities measure and communicate their efforts to sustainable development, tend to focus on local economy; yet much more could be analysed to increase the universities' potential as contributors to SD.

If higher education institutions want to become change agents and actively engage in sustainable development at regional level, they can prioritise two main activities (Peer \& Stoeglehner, 2013). Firstly, they can customise education programmes by co-creation of curricula with local communities for local and regional needs (Peer \& Stoeglehner, 2013). Secondly, universities can lead or be involved in co-research (e.g. participatory research) to empower and collaborate with local communities (i.e. equal bilateral/ multilateral knowledge exchange) (Peer \& Stoeglehner, 2013). The case studies presented by Kusakabe (2013), suggest that there is a positive correlation between social participation in developing city projects and the level of sustainability achieved, emphasizing the importance of community involvement for sustainable development.

Literature is focused on large local sustainability partnerships (such as Local Agenda 21s) in which universities are one type of partner among many (e.g. MacDonald et al., 2018). The literature also focuses on the potential and importance of universities' role, and the associated challenges and impact determinants. However, there is a paucity of literature which reports on empirical findings of universities actual contributions towards sustainable development efforts within their local communities (Peer \& Stoeglehner, 2013). Therefore, this paper aims at addressing that need by analysing and reporting on regional sustainable development initiatives of universities.

\section{The need for research}


Universities have been increasingly incorporating more responsibilities when it comes to their contributions to society. Besides including sustainability in operations, teaching, outreach and research, among others, their initiatives at the local level have a fundamental impact in the context they are inserted on.

According to a practical guide from the European Commission (2011), on how to connect universities to regional growth, these educational institutions can be anchor institutions in local economies as major employers across a wide range of occupations, purchasers of local goods and services, besides being contributors to cultural life and the built environment of cities. Even though the guide focuses on contributions of universities to regional development, in a sustainable way, it focuses on the European context; therefore, a global approach could be considered a gap in literature and it justifies the need for international studies regarding universities initiatives at the local level. Shiel et al. (2016) point out the need to document and promote countries experiences, as the approach utilised in this paper, once the plurality and diversity of experiences can offer useful insights.

Another point which justifies the importance of such discussion is the fact that universities have only recently engaged in this role of regional/local contribution (OECD, 2007). The past years represent a great evolution in this regard, but the actions tend to be isolated i.e. not performed in a systematic way. Understanding how it happens and shedding light to the topic in different contexts is paramount for universities to improve in their own actions.

\section{Methodology}

To address the research gap seen in respect of identifying the role played by universities in local sustainability efforts, an international qualitative survey was undertaken. The survey instrument was prepared based on the paucity of information in the literature review and on the suggestions from practical guidance to improve the contribution of universities to regional development (European Commission, 2011). The data collection matrix was designed, tested and deployed in order to gather information on the local and regional development initiatives undertaken by a set of 22 universities from different countries. The pre-test was carried out in the universities from the authors to verify the comprehension and pertinence of the questions. This sample is indeed small in nature, but since the purpose of the study was to offer a qualitative assessment of trends- rather than a superficial one - it was deemed as commensurate with the aims of the study.

The matrix was composed by three parts:

a) Networking

\begin{tabular}{l|l} 
Description & Networks development initiatives are concentrated on encouraging
\end{tabular} and supporting inter-firm collaboration, institutional development, and support in targeted industrial sectors. The sectors are usually targeted at those that offer the most local economic development potential. (European Commission, 2011).

Evidences $\quad$ On the networking section, the respondents could evaluate the quality of sustainability network with local organisations, describe which kind of organisations are usually partners in cooperation, the frequency of cooperation, for how long cooperation have been undertaken and factors that hinder cooperation. 
b) Cooperation in local initiatives

Description $\quad$ Cooperation in local initiatives involves how the universities are supporting the regional development in terms of education, research and innovation actions (European Commission, 2011).

Evidences $\quad$ In the section regarding cooperation in local initiatives, the matrix allowed evaluations through which initiatives universities usually cooperate with local organisations and which thematic areas are part of cooperation. The university satisfaction with the results of cooperation was also evaluated

c) Case Studies

Description

They illustrate (by use of examples from different countries) some of the potential initiatives that can be used to maximize the contribution of universities to sustainability at local level. According to European Commission (2011), case studies help inform lessons learnt suggest 'good practice'.

Evidences $\quad$ The last part is composed by case studies presented by universities, describing actions undertaken and what could be done to achieve a better relation and/or intensify cooperation efforts at the local level.

These were structured in a way that allowed the study to gather essential information on the actions performed by the Universities at the local level, with 10 open- and close-ended questions. The survey instrument is presented in Appendix A and it was answered by the administration staff with know-how to transmit the requested information.

The definition of the group of universities that would be part of the study and the procedure for data collection followed two steps:

i. Invitation of authors/researchers available to contribute to this paper, from the network of universities participating at Inter-University Sustainable Development Research Programme (https://www.haw-hamburg.de/en/ftznk/programmes/iusdrp.html) and the World Sustainable Development Research and Transfer Centre (https://www.hawhamburg.de/en/ftz$\mathrm{nk} /$ programmes/wsd-rtc.html). Other studies were published using the same network and have in common the idea of discussing different topics with a global vision (Ávila et al., 2017; Leal Filho et al., 2017). The intention here was to involve at least 20 universities, representing an international study; therefore, the sample justification relies on the availability and willingness to contribute and participate in this research.

ii. The matrix was then sent to the authors defined in the previous step, so that they could collect data from their university.

Upon receiving the responses, these were manually processed. Data from open questions was investigated by content analysis, a technique that involves reading and interpreting the material in a progressive and systematic way, in order to categorise the information (Moraes, 1999). The process was operationalized through the support of the software Nvivo, utilised specifically for qualitative studies and used in similar studies 
(Mozzato and Grzybovski, 2011; Ávila et al, 2017). The gathered data is presented and discussed in the next section.

\section{Results and Discussion}

A total of 22 answers was received, from both industrialised (Canada, France, Italy, Latvia, Portugal, Serbia, United Kingdom, USA) and developing countries (Brazil, Ghana, India, Malaysia, Thailand), which demonstrate the qualitative nature of this study. Most of the universities have a public nature, as shown in Table 1.

Table 1. Distribution of universities according to their country and nature

\begin{tabular}{|c|c|c|c|c|}
\hline Country & \multicolumn{2}{|c|}{$\begin{array}{c}\text { Industrialised } \\
59 \%\end{array}$} & \multicolumn{2}{|c|}{$\begin{array}{c}\text { Developing } \\
41 \%\end{array}$} \\
\hline Nature & $\begin{array}{c}\text { Public } \\
55 \%\end{array}$ & $\begin{array}{c}\text { Private } \\
4 \%\end{array}$ & $\begin{array}{c}\text { Public } \\
23 \%\end{array}$ & $\begin{array}{c}\text { Private } \\
18 \%\end{array}$ \\
\hline
\end{tabular}

\subsection{Networking}

According to the results of the Networking section (Figures 1 and 2), each university evaluated the quality of their sustainability actions at local level.

More than $80 \%$ of the respondents rated their local networks positively, while $18 \%$ showed some dissatisfaction by evaluating them as "rather weak". Regarding the frequency of the cooperation, $50 \%$ of the answers stated "sometimes", followed by "often" and "very often", representing more than $45 \%$. Only a small percentage of universities rarely cooperate with local organisations.

Most universities have been cooperating on SD issues with local organisations for 5-10 years, or even more. A minority has been investing in that issue for less than 4 years. There were no significant differences in respect of networking between industrialised or developing countries, which means that networking is being actively pursued among both categories of nations. 
Figure 1. Results of the Networking section, regarding quality, frequency and timeframe of local initiates

(a) How well would you consider your local network, i.e. your links on matters related to sustainable development with local organisations?

- Excellent

- Very good

$\triangle$ Good

Rather weak

- Very weak

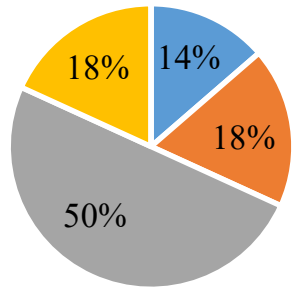

(b) How frequently do you cooperate with local organisations on sustainable development issues?

- Very often

Often

$\because$ Sometimes

Seldom

- Hardly ever

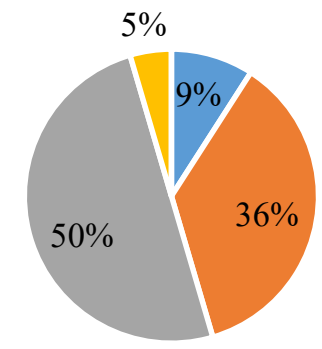

(c) For how long have you been cooperating on sustainable development issues, with local organisations?

- Over 10 years

- Between 5 and 10 years

- Between 3 to 4 years

- Between 1 and 2 years

- One year or less

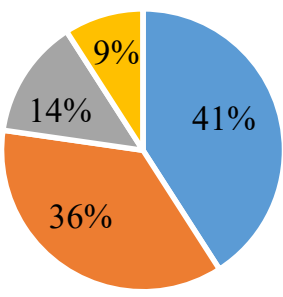

According to Figure 2(a), lack of resources/incentives is the factor that hinder local cooperation the most. Lack of coordination is also among those which negatively impact the success of this practice. Some comments from the survey showed that, as leadership plays a crucial role in deciding the priorities of a university, changes in the leading group often disrupts the local engagement. It reinforces the importance of embedding sustainability in the 
academic and operational processes, as well as in the culture and structure of the institution (Bina et al., 2016; Leal Filho, Shiel and Paço, 2015; Lozano et al., 2015).

A similar argument is also presented by Fichter and Tiemann (2018), regarding factors influencing university support for sustainable entrepreneurship. For these authors, key persons are crucial to initiate and promote university support for their activities and guarantee success for it. Zilahy and Huisingh (2009), note that academics should play an active part in helping form strategies and to implement changes that lead regional sustainability.

Figure 2. Results of the Networking section, regarding factors that hinder cooperation and other partners

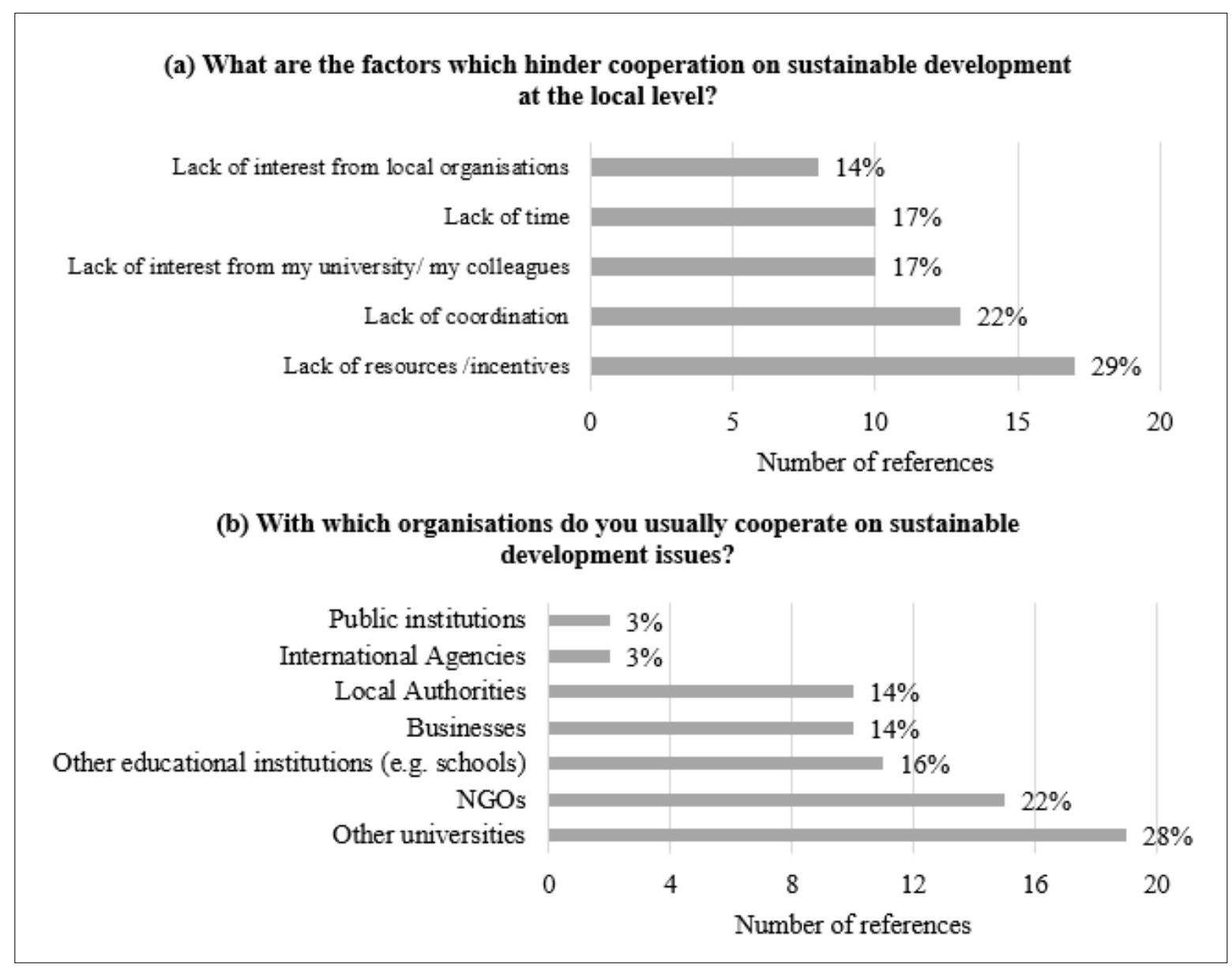

Other comments also highlighted the importance of applying both top-down and bottom-up approaches for cooperation between universities and local community to succeed. Examples from the literature are also clear when mentioning the importance of these approaches for the success of regional development processes (Peer \& Stoeglehner, 2013). In fact, the combination of approaches seems to be considered a good strategy to overcome the factors that hinder cooperation, including good coordination among advocacy, policy and also STEM (Science, Technology, Engineering and Mathematics), as mentioned by the respondents.

Lack of interest from colleagues was also discussed as one reason that creates difficulties for universities to intensify efforts at local level. Sustainability is still seen as something less important in comparison to other research areas (especially when it comes to environmental issues), therefore some teams end up focusing on conventional approaches from their expertise. 
Other mentioned factors that affect cooperation were lack of interest from social partners and municipalities and also disciplinary silos. Some partners may be interested in other topics rather than in sustainability when it comes to cooperation or might not understand fully what sustainability encompasses. Regarding disciplinary silos, it happens when specialists become isolated in their own academic area, interacting less with other colleagues and transdisciplinary activities (Blanco-Portela et al., 2017; Zilahy and Huisingh, 2009) and this is definitely not a desired approach for sustainability (Stevens \& Kanie, 2016).

These factors are, at some extent, connected with the results presented in Figure 2(b). Most universities have been cooperating more with other universities and NGOs. Local authorities, businesses, international agencies and public institutions have probably less priority considering the challenges discussed above.

\subsection{Cooperation in Local Initiatives}

When it comes to initiatives taken (Figure 3), support in organising/running sustainability related events at the university and support in joint sustainability projects are those which receive more attention. This support is especially given to other universities and NGOs. Support in management/administration tasks on sustainability was the initiative that received the least amount of answers and one third of them focus on contributing to other universities.

Figure 3. Results of the Cooperation in Local Initiatives section, regarding initiatives taken 


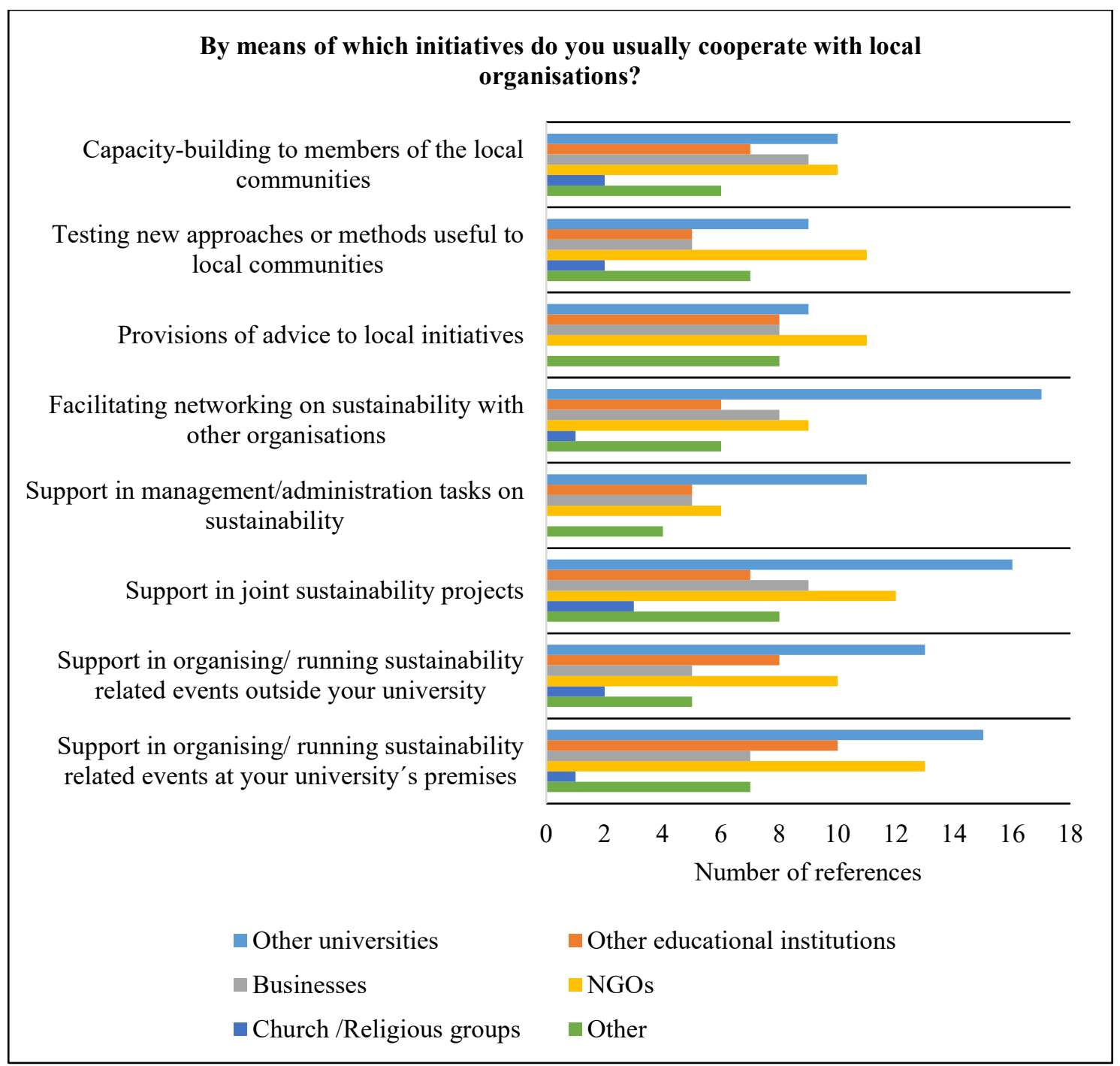

In the category "other", the respondents mentioned actions mainly related to public management, assistance to government agencies, local authorities and capacity-building to members of the local community/civil society.

In addition to asking initiatives taken by universities, the survey also questioned thematic areas with major focus of cooperation with local community, as shown in Figure 4. The main areas are the practice of sustainable development, the SDGs and support to concrete occasions/case studies. As in the last question, the most common partners are other universities and NGOs, although local businesses also received great attention in this topic. "Others" mentioned by the respondents include government agencies and local authorities. This is in line with the study performed by Soini et al. (2018), regarding the cooperation between sustainability centres of universities and NGOs, local communities, businesses and administration/policy.

It was an outstanding result to have such a great number of activities focusing on the SDGs, which are indeed increasing in terms of publication, research and support for implementation, especially in universities (Caiado et al., 2018; Salvia et al., 2018).

Figure 4. Results of the Cooperation in Local Initiatives section, regarding thematic areas 


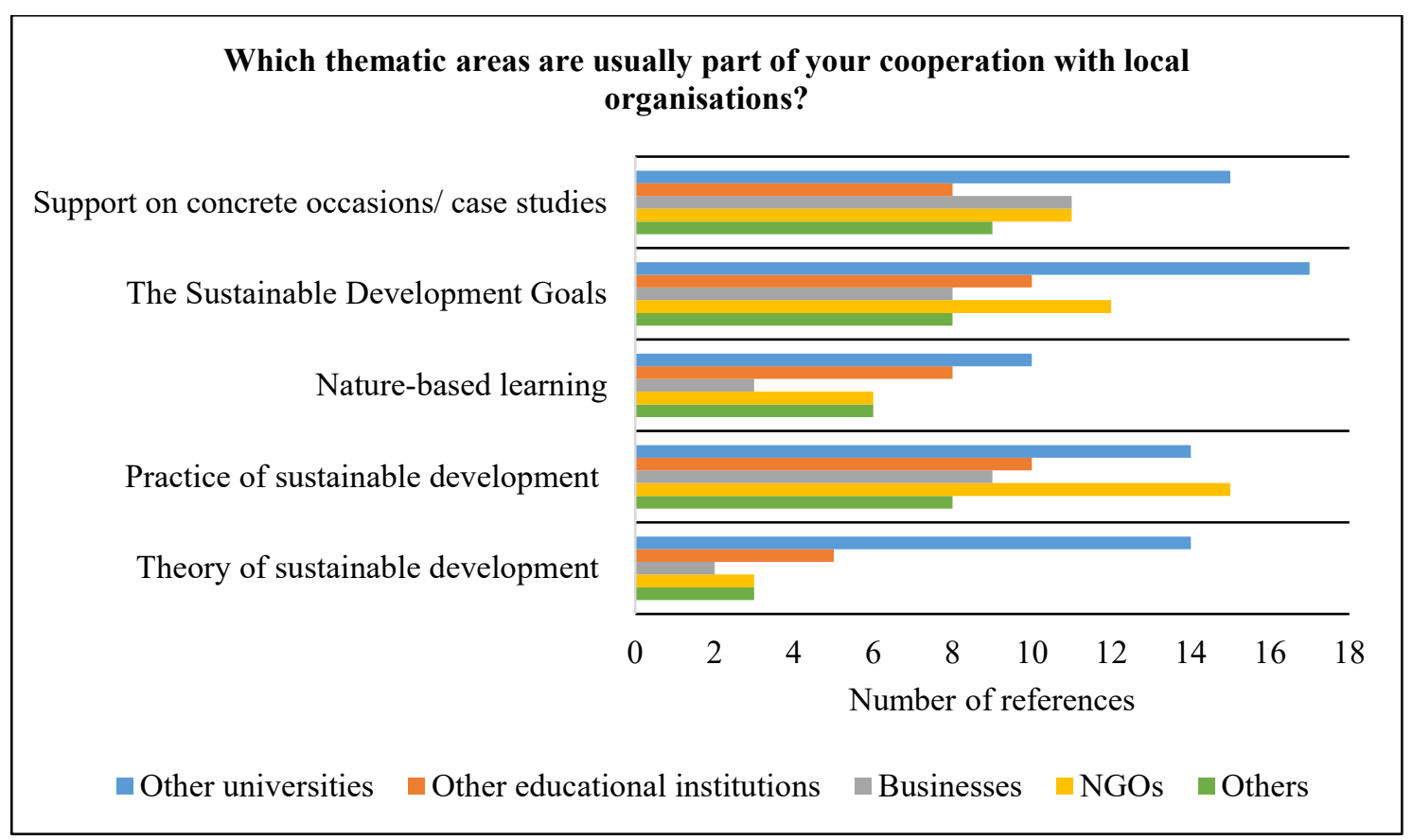

In general, as shown in Figure 5, universities are satisfied with the results of cooperation with local community. Regardless of the level of satisfaction, many respondents have discussed what should be done to achieve a better relation and/or intensify cooperation efforts at the local level, besides challenges that should be overcame. The main topics are presented as follows, based on the qualitative analysis of the results and comments from all respondents:

Figure 5. Results of the Cooperation in Local Initiatives section, regarding satisfaction with the results

How satisfied are you with the results of the cooperation on sustainable
development, achieved to date?

- From sporadic to regular activities

Currently, sustainability initiatives at local level tend to be quite sporadic and depend on personal contacts and interest from a few interested groups, lacking a coordination process. Since the efforts are driven by individual faculty members who are not always able to continue the projects over time, the entire university curriculum should consider local sustainability needs and create structures and processes that can enable academic delivery and real impact.

Short term visions (only during specific extension/research projects) are prejudicial to the success of local sustainable development projects. Giving them a regular and long-lasting 
programme would be exceptionally positive, not only in terms of better management, but also to concrete results.

- Development of a formal network

In order to potentialize the efforts and intensify the actions at local level, the involvement and support of national or international networks is fundamental. Main local public bodies could also organize and lead multi-actors' groups on working on different sustainability-related topics. That could be a good way to create network and synergies among different stakeholders (universities, NGOs, schools, associations, private companies) interested in sustainable development, which could lead to new projects and activities in this field.

\section{- Financial support}

According to the results, lack of resources/incentives is the main factor that hinders cooperation. The experiences shared by the universities reinforce that, since financial support seems to be a limiting factor. The partners could be more effective if more resources were available for a coordinating body to assist partnerships and maintain ongoing projects. Capital to cover initiatives' costs and adequate funding from government and corporate donations are also among the topics discussed.

\section{- Commitment}

Having all stakeholders committed and the local community involved is crucial. There is a need to empower the stakeholders on the project so as they will give full support. In addition, government involvement, integration of all departments in a university, greater strategic leadership and commitment from the top are also important topics for the success of cooperation.

More staff time needs to be dedicated to these activities and the team needs to be valued by the senior management. It is imperative that Academia understands and studies local issues and that the partners (businesses, NGOs, among others) take into account the academic research. A common language between different actors (including academia, business, government) must be improved and unfortunately this is an under investigated area in sustainable development.

Universities, local government, the private and voluntary sectors need to work together in order to identify community networks and their respective key individuals, which connect several agents from many different areas. These key individuals should exercise their leadership to disseminate and encourage concrete practices of sustainable development that are aligned with local needs and resource availability. The participation in such practices represent an important role and, therefore, they feel responsible for it. The empowerment and commitment of local leaders is another factor that should be highlighted for the success of cooperation.

\section{- Connection with the Sustainable Development Goals}

Universities have been making great efforts in actions to help the society be more sustainable, however, this is not always perceived by the actors involved. In fact, many local partners do not seem aware of the Sustainable Development Goals (SDGs). Almost all actions can be engaged in one of the SDGs, but most of the people do not seem to know what they are. This is a worrying trend due to the importance of the SDGs. 
Other recommendations include a permanent source of funding for cooperation, formal support from national bodies, appropriate recognition of professors/scholars involved in activities of cooperation, increased cooperation and coordination at all levels of development policy, increased community participation and ownership of sustainable designed interventions. More disseminating events, such as meetings and workshops are also among the recommendations.

Moreover, sustainability should be deeper embedded in the local policies and practices, contributing to strength institutional capacity to identify novel approaches for improving sustainability in community-based interventions.

\subsection{Case studies}

Finally, since the case studies provided interesting insights, these are herewith presented. First, it should be explained that each studied university could present some case studies on the matrix, which could describe their experiences with local community projects. Brief notes about these cases are presented in Table 2, classified according to their primary focus (environmental, social or economic) and university country (industrialised or developing).

In developing countries, environmental actions tend to focus more on local issues, such as conservationist agricultural practices, conservation of local species, air and water quality. Social actions are also related to local communities, through different approaches, such as ecotourism, guidance on managing small businesses, analysis of effects of extreme events and importance of risk management, women's empowerment and, most commonly, education for sustainability. Economic actions included responsible financial sustainability and alternative livelihoods.

On the other hand, in industrialised countries universities tend to work more in environmental issues related to green areas and community gardens, resilience, waste management, among others. The social approach is similar to developing countries, focusing on education for sustainable development and possibly a little bit more on the Sustainable Development Goals. The SDGs are also involved in economic actions.

These elements showcase the diversity of initiatives performed. More case studies and details could have been included, but they were omitted due to space constraints. Future efforts should be made to identify some of the most interesting and promising innovations, which will be the subject of a further paper.

Table 2. Examples of initiatives of cooperation between universities and local community

\begin{tabular}{|c|c|}
\hline $\begin{array}{l}\text { Primary focus } \\
\text { and country } \\
\text { classification }\end{array}$ & Cases \\
\hline \multirow{3}{*}{ 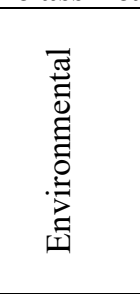 } & $\begin{array}{l}\text { Support to cities to develop their local plans of sustainable development, declarations of } \\
\text { cities as green cities, development of local Climate Change policy and action plans. }\end{array}$ \\
\hline & $\begin{array}{l}\text { Project focused on raising awareness among citizens and young generations of the } \\
\text { importance of investing in "green capital". University help care and enhance city's arboreal } \\
\text { heritage. }\end{array}$ \\
\hline & $\begin{array}{l}\text { National University Network for Sustainable Development: first experience of coordination } \\
\text { and sharing between universities committed to the topic of environmental sustainability and }\end{array}$ \\
\hline
\end{tabular}


social responsibility. The main aim is to spread culture of sustainability, both within and outside the universities.

Cooperation for local management, focused on resilient cities and disaster risk management.

Workshops with different sectors (university, municipal administration, public enterprises,

NGOs) helped develop a model for urban Disaster Risk Management.

In cooperation with schools, the university project focused on installing a community garden and creating a programme for students and community members. Nature trails between schools and the garden were also industrialised.

Work with city officials to create rain gardens on campus and in town to mitigate storm water runoff. This protected a local river that contains some of the highest biodiversity in the region.

Events on campus for school age children and youth, focusing on, for example, increasing girls and indigenous youth in STEM fields, supporting secondary students interested in solving complex problems, hacking for water solutions, an environmental competition, among others.

University as part of the Local Authority Strategic Climate Change Education Group.

Partnership among businesses, local authority and university focused on waste management.

Collaboration with NGOs to produce compost (organic fertilizer) from organic waste.

Collaboration with companies and other universities to reduce energy consumption of municipal wastewater treatment plants (WWTPs).

Funding support to design, implement and evaluate sustainable Water Sanitation and Hygiene (WASH) solutions in communities.

Project aimed at increasing the level of environmental health security. It deals with the development of technology for air cleaning in highly polluted urban micro environments, helping promote public awareness on the importance of innovative technologies in implementing SDG 11 and SDG 13.

Study on the influence of university sustainability on management discourse.

Project to encourage the adoption of conservationist agricultural practices in the local community.

Extension activity for conservation of nature and important local species.

Community project focused on working with local fishers, community leaders and a large commercial shrimp farm to come out with solution acceptable to all parties when it comes to a sustainable management of effluents to avoid environmental degradations.

Program focused on Localizing Sustainable Development Goals (SDGs), especially Goal 11

- Making cities inclusive, safe, resilient, and sustainable. Workshops helped identify the needs of the local community and the formulation of the strategies for the development of a preliminary strategy for the neighbourhood.

Research on how emergency situations affect ability of communities to move forward on the path of the sustainable development, by analysing their capacity to respond to multidimensional security threats promptly and efficiently.

Programme that matches community organisations (businesses, NGOs) with students' volunteer time.

Small scale initiative supporting an organisation that inspires young women (typically aged 16-25 years old) to embark on careers in sustainability. The university supports the project by providing staff time (for presentations) and rooms on campus.

Engagement on Sustainable Development Solutions Network through partnership with NGOs, local businesses, among others. Events are industrialised to promoted the SDGs, leveraging research and teaching for implementing those.

Involvement of municipality representatives as guest lecturers at university, seminars in city, articles in local newspaper, among others, helping at sustainable development planning.

Identifying socio-economic conditions of people displaced due to industrial projects, support these communities, formulates CSR (Corporate Social Responsibility) policy for the organization; education programmes to sensitize managers about displacement and rehabilitation and frame policies for compensation of those people.

Work with local slum dwellers, helping local businesses by giving free advice on managing such small businesses. Students are encouraged to know, interact and help local poor slum 


\begin{tabular}{|c|c|c|}
\hline & & $\begin{array}{l}\text { dwellers in various aspects of sustainable development like energy use, livelihood and } \\
\text { gender. }\end{array}$ \\
\hline & & $\begin{array}{l}\text { Sharing evidence on scientific research and translating evidence into policy actions to } \\
\text { improve development outcomes. }\end{array}$ \\
\hline & & $\begin{array}{l}\text { Development of a sustainable alternative livelihood through the establishment of } \\
\text { community-based ecotourism. }\end{array}$ \\
\hline & & $\begin{array}{l}\text { Community project focused on Disaster Risk Reduction; risk zones are identified; local } \\
\text { residents are prepared for actions and to assist evacuation. Evacuation drills are also } \\
\text { conducted. }\end{array}$ \\
\hline & & $\begin{array}{l}\text { Project focused on examining from the sustainability point of view weather extreme events, } \\
\text { their effects and the effectiveness of responses by government, aid agencies and } \\
\text { communities. }\end{array}$ \\
\hline & & $\begin{array}{l}\text { Partnership with a non-profit civil association aiming to encourage the community in terms } \\
\text { of sustainable development, through monthly viewing of movies whose themes were related } \\
\text { to sustainability }\end{array}$ \\
\hline & & $\begin{array}{l}\text { Empowerment of women through a local Women Development Corporation, focusing on } \\
\text { SDG } 5\end{array}$ \\
\hline & & $\begin{array}{l}\text { Program aiming to carry out actions based on the assumption that people need to think the } \\
\text { city as a pedagogical territory, in the perspective of an educating city. }\end{array}$ \\
\hline \multirow{3}{*}{ 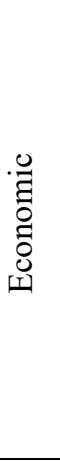 } & 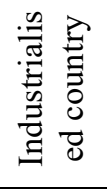 & Integrating SDG thinking into the research agenda of a professional body \\
\hline & \multirow{2}{*}{ 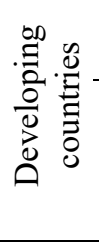 } & Comparison of Sustainability of Financial Systems and Budgeting for institutions \\
\hline & & $\begin{array}{l}\text { Development of a sustainable alternative livelihood for local community using mulberry } \\
\text { trees. The project built a hybrid solar dryer to dry the mulberry products, being the local } \\
\text { community groups considered innovative farmers and also entrepreneurs in the mulberry } \\
\text { industry. }\end{array}$ \\
\hline
\end{tabular}

The literature demonstrates that universities are developing projects with local approaches and acting as partners for local sustainability. Some examples show specific experiences on the union of this issue with the SDGs, international agencies, local authorities, amongst others, but little was actually discussed in terms of a global overview. Therefore, a general and international report on sustainable development initiatives of universities acting locally was much desired. In this sense, this research contributed to gathering new knowledge in three different ways: first, by putting forward this global overview; second, by bringing experiences from universities of different countries and checking that there is no significant difference between industrialised and developing countries when it comes to frequency, duration, and satisfaction of cooperation (but some differences might be observed when it comes to undertaking projects with the local community); and third, by sharing experiences of how universities have been dealing with this role and local sustainability.

\section{Conclusions}

This paper was an attempt to address the current literature gap in respect of reporting empirical findings on the contributions from universities towards sustainable development within their local communities. It did so by both opening a discussion on this matter, and by reporting on examples of regional sustainable development initiatives being performed by universities round the world.

A group of 22 universities took part in this research, from both industrialised and developing countries. Being a qualitative study means that the sample was small in principle, 
but the data gathered allows a profile to be built, of the extent to which universities are engaging with their communities on matters related to sustainable development. On a second stage and provided external funding is available, larger samples may be investigated.

Contrary to initial expectations, the sampled countries have not shown consistent differences when it comes to the analysed data. This suggests that opportunities and constraints in pursuing sustainability seem to be similar to universities in both the industrialised and developing world.

In general, universities rated their local networks positively and they tend to cooperate with local community on occasions. Indeed, most of them have been cooperating for more than 5 years, which is a positive result. This is also a promising prospect in that such cooperation modalities may continue to be pursued in the future.

Lack of resources/incentives and lack of coordination were considered the factors that hinder local cooperation the most. Support in organising/running sustainability related events at a given university, and support to joint sustainability projects are among those activities which receive favourable responses. It seems that more of them are needed. The main thematic areas for cooperation are practices of sustainable development; actions related to the SDGs, and support to concrete occasions or case studies.

Despite all the positive examples of best practices, there is still various challenges seen in addressing the many unsustainable trends seen at the local level, among which mention may be made to the poor handling of wastes, sub-optimal uses of energy and other similar problems. It seems that the nature of the needs is quite wide, which offers ample scope for cooperation between universities and communities across a range of areas.

Universities may be able to enhance their role in the local sustainability context in the following ways:

a) By better promoting their work on sustainable development at the local level, hence informing local communities

b) By better pursuing partnerships and joint initiatives with local organisations on selected topics of mutual interest

c) By "listening" to the needs of local communities by means of dialogues and information events, and trying to consider their needs when designing research projects

d) By making their know-how more widely available, so that they may support local sustainability efforts more systematically, as opposed to do so on a "ad hoc" basis, as it is largely the case today.

This study has provided a contribution to the state of the art in respect of the identification of the local engagement of universities on matters related to sustainable development at the local level. The scientific added value of this research is related to the better understanding of the interactions between universities and local communities, and by shedding light on the modalities of cooperation and some of the opportunities which may be used in the future. It is believed that local cooperation's may bring about mutual benefits and may catalyse synergies on sustainable development issues at the local level. As to the future, it would seem sensible to offer information and training programmes on local partnerships to staff at universities, so that they may be in a better position to take the many advantages local cooperation on matters related to sustainable development offer to them. To the same level, local authorities and communities may benefit from opportunities to link up with their local universities and take advantage of the comprehensive body of information and knowledge they have.

Combined, these measures may support the execution of initiatives led by universities on matters related to sustainable development, at the level they matter most: the local one. 


\section{Acknowledgements}

The authors would like to thank Lindsay Falvey, John Leake, Ng Theam Foo, Su Yean Teh, Marlinah Muslim, Chan Siok-Yee, Sharifah Nurlaili Farhana Syed Azhar and Ann Hindley for their contribution to this paper.

\section{References}

Ávila, L. V., Leal Filho, W., Brandli, L. L., Macgregor, C. J., Molthan-Hill, P., Özuyar, P. G., Moreira, R. M., 2017. Barriers to innovation and sustainability at universities around the World. Journal of Cleaner Production, 164, 1268-1278.

Bantanur, S., Mukherjee, M., Shankar, R., 2015. Emerging dimensions of sustainability in institutes of higher education in India. International Journal of Sustainable Built Environment, 4, 323-329.

Bina, O., Balula, L., Varanda, M., Fokdal, J., 2016. Urban studies and the challenge of embedding sustainability: A review of international master programmes. Journal of Cleaner Production, 137, 330346.

Blanco-Portela, N., Benayas, J., Pertierra, L. R., Lozano, R., 2017. Towards the integration of sustainability in Higher Education Institutions: A review of drivers of and barriers to organisational change and their comparison against those found of companies. Journal of Cleaner Production, 166, 563-578.

Blume, L., Brenner, T., Buenstorf, G., 2017. Universities and sustainable regional development: introduction to the special issue. Review of Regional Research, 37(2), 103-109.

Boks, C., Diehl., J. C., 2006. Integration of sustainability in regular courses: experiences in industrial design engineering. Journal of Cleaner Production, 14 (9-11), 932-939.

Breznitz, S. M., Feldman M. P., 2012. The engaged university. Journal of Technology Transfer, 37, $139-157$.

Caiado, R. G. G., Leal Filho, W., Quelhas, O. L. G., de Mattos Nascimento, D. L., Ávila, L. V., 2018. A literature-based review on potentials and constraints in the implementation of the sustainable development goals. Journal of Cleaner Production, 198, 1276-1288.

Cebrián, G., 2017. A collaborative action research project towards embedding ESD within the higher education curriculum. International Journal of Sustainability in Higher Education, 18(6), 857-876.

CRE-Copernicus, 1994. COPERNICUS - The University Charter for Sustainable Development. http://www.iau-hesd.net/sites/default/files/documents/copernicus.pdf (accessed 7 August 2018).

Disterheft, A., da Silva Caeiro, S. S. F., Ramos, M. R., de Miranda Azeiteiro, U. M., 2012.

Environmental Management Systems (EMS) implementation processes and practices in European higher education institutions-Top-down versus participatory approaches. Journal of Cleaner Production, 31, 80-90.

Elliott, L., Ryan, M., Wyborn, C., 2018. Global patterns in conservation capacity development. Biological Conservation, 221, 261-269.

Ensign M., 2017. Let's Train 'Extension Agents' for the 21st Century. The Chronicle of Higher Education. https://www.chronicle.com/article/Let-s-Train-Extension/240664 (accessed 19 June 2018). 
European Commission, 2011. Connecting Universities to Regional Growth: A Practical Guide. http://ec.europa.eu/regional_policy/sources/docgener/presenta/universities2011/universities2011_en.p df (accessed 23 August 2018)

Evans, J., Jones, R., Karvonen, A., Millard, L., Wendler, J., 2015. Living labs and co-production: university campuses as platforms for sustainability science. Current Opinion in Environmental Sustainability, 16, 1-6.

Fichter, K., Tiemann, I., 2018. Factors influencing university support for sustainable entrepreneurship: Insights from explorative case studies. Journal of Cleaner Production, 175, 512-524.

Findler, F., Schönherr, N., Lozano, R., Stacherl, B., 2019. Assessing the Impacts of Higher Education Institutions on Sustainable Development-An Analysis of Tools and Indicators. Sustainability, 11(1), 59, https://doi.org/10.3390/su11010059

Gunasekara, C., 2006a. The generative and developmental roles of universities in regional innovation systems. Science and Public Policy, 33(2), 137-150.

Gunasekara, C., 2006b. Reframing the role of universities in the development of regional innovation systems. The Journal of Technology Transfer, 31(1), 101-113.

Hajer M., Nilsson, M., Raworth, K., Bakker, P., Berkhout, F., de Boer, Y., Rockstrom, J., Ludwig, K., Kok, M., 2015. Beyond Cockpit-ism: Four Insights to Enhance the Transformative Potential of the Sustainable Development Goals. Sustainability, 7(2), 1651-1660.

Hayter, C. S., Cahoy, D. R., 2018. Toward a strategic view of higher education social responsibilities: A dynamic capabilities approach. Strategic Organization, 16(1), 12-34.

Horlings, I., Padt, F., 2013. Leadership for sustainable regional development in rural areas: bridging personal and institutional aspects. Sustainable Development, 21(6), 413-424.

James, C.D., Schmitz, C.L., 2011. Transforming sustainability education: ethics, leadership, community engagement, and social entrepreneurship. International Journal of Business and Social Science, 2(5), 1-10.

Karatzoglou, B., 2013. An in-depth literature review of the evolving roles and contributions of universities to Education for Sustainable Development. Journal of Cleaner Production, 49, 44-53.

Katiliute, E., Daunoriene, A., Katkute, J., 2014. Communicating the sustainability issues in higher education institutions World Wide Webs. Procedia - Social and Behavioral Sciences, 156, 106-110.

Kusakabe, E., 2013. Advancing sustainable development at the local level: The case of machizukuri in Japanese cities. Progress in Planning, 80, 1-65.

Leal Filho, W., Brandli, Castro, P., Newman, J. (Eds.), 2017a. Handbook of Theory and Practice of Sustainable Development in Higher Education. Volume 1. Springer Berlin, ISBN 978-3-31947868-5.

Leal Filho, W., Skanavis, C., do Paço, A., Rogers, J., Kuznetsova, O., Castro, P. (Eds.), 2017b. Handbook of Theory and Practice of Sustainable Development in Higher Education. Volume 2. Springer, Berlin. ISBN 978-3-319-47889-0. 
Leal Filho, W., Shiel, C., Paço, A. D., 2015. Integrative approaches to environmental sustainability at universities: an overview of challenges and priorities. Journal of Integrative Environmental Sciences, 12(1), 1-14.

Leal Filho, W., Wu, J., Brandli, L. L., Ávila, L. V., Azeiteiro, U., Caeiro, S., Madruga, L. R. R. G., 2017. Identifying and overcoming obstacles to the implementation of sustainable development at universities. Journal of Integrative Environmental Sciences, 14, 93-108.

Lozano, R., Ceulemans, K., Alonso-Almeida, M., Huisingh, D., Lozano, F. J., Waas, T., Lambrechts, W., Lukman, R., Hugé, J., 2015. A review of commitment and implementation of sustainable development in higher education: results from a worldwide survey. Journal of Cleaner Production, 108, 1-18.

Lozano, R., Lozano, F.J., Mulder, K., Huisingh, D., Waas, T., 2013a. Advancing Higher Education for Sustainable Development: international insights and critical reflections, Journal of Cleaner Production, $48,3-9$.

Lozano, R., Lukman, R., Lozano, F.J. Huisingh, D., Lambrechts, W., 2013b. Declarations for sustainability in higher education: becoming better leaders, through addressing the university system, Journal of Cleaner Production, 48, 10-19.

MacDonald, A., Clarke, A., Huang, L., Roseland, M., Seitanidi, M. M., 2018. Cross-Sector Partnerships (SDG \#17) as a Means of Achieving Sustainable Communities and Cities (SDG \#11). In W. Leal Filho (Ed.). Handbook of Sustainability Science and Research. New York, USA: Springer Publishing Company.

Moon, C. J., Walmsley, A. Apostolopoulos, N., 2018. Governance implications of the UN higher education sustainability initiative. Corporate Governance: The International Journal of Business in Society, 18(4), 624-634.

Moraes, R. 1999. Análise e conteúdo. Ver. Educ. Port. 9(37), 7-32.

Mosier, S., 2015. Does the Gown Help the Town? Examining Town-Gown Relationship Influence on Local Environmental Sustainability in the United States. International Journal of Public Administration, 38(11), 769-781.

Mozzato, A.R., Grzybovski, D., 2011. Análise de Conteúdo como técnica de análise de dados qualitativos no campo da administração: potential e desafios. Revista de Administração Contemporânea RAC, 15(4), 731-747.

OECD, 2007. Higher Education and Regions: Globally Competitive, Locally Engaged. http://www.oecd.org/document/25/0,3343,en_2649_201185_39329177_1_1_1_1,00.html (accessed 23 August 2018)

Pallant, E., Choate, B, Haywood, B. (In Press). How do you teach undergraduate university students to contribute to UN SDGs 2030? In Universities as Living Labs for Sustainable Development, World Sustainability Series. Springer, Berlin.

Peer, V., Penker, M., 2016. Higher education institutions and regional development: a metaanalysis. International Regional Science Review, 39(2), 228-253.

Peer, V., Stoeglehner, G., 2013. Universities as change agents for sustainability-framing the role of knowledge transfer and generation in regional development processes. Journal of Cleaner Production, 44, 85-95. 
Radinger-Peer, V., Pflitsch, G., 2017. The role of higher education institutions in regional transition paths towards sustainability. Review of Regional Research, 37(2), 161-187.

Salvia, A. L., Leal Filho, W., Brandli, L. L., Griebeler, J. S., 2018 (In Press). Assessing research trends related to sustainable development Goals: Local and global issues. Journal of Cleaner Production, https://doi.org/10.1016/j.jclepro.2018.09.242.

Sammalisto, K., Lindhqvist, T., 2008. Integration of Sustainability in Higher Education: A Study with International Perspectives. Innovative Higher Education, 32, 221-233.

Santos, J. M., Horta, H., 2018. The research agenda setting of higher education researchers. Higher Education, 76(4), 649-668.

SDSN Australia/Pacific, 2017. Getting started with the SDGs in universities: A guide for universities, higher education institutions, and the academic sector. Australia, New Zealand and Pacific Edition. Sustainable Development Solutions Network - Australia/Pacific, Melbourne. http://ap-unsdsn.org/wpcontent/uploads/2017/08/University-SDG-Guide_web.pdf (accessed 12 July 2018).

Sedlacek, S., 2013. The role of universities in fostering sustainable development at the regional level. Journal of Cleaner Production, 48, 74-84.

Shiel, C., Leal Filho, W., do Paço, A., Brandli, L., 2016. Evaluating the engagement of universities in capacity building for sustainable development in local communities. Evaluation and program planning, 54, 123-134.

Soini, K., Jurgilevich, A., Pietikäinen, J., \& Korhonen-Kurki, K. (2018). Universities responding to the call for sustainability: A typology of sustainability centres. Journal of Cleaner Production, 170, $1423-1432$.

Soliman, S., Anchor, J., Taylor, D., 2018. The international strategies of universities: deliberate or emergent?. Studies in Higher Education, 1-12.

Stevens, C., Kanie, N., 2016. The transformative potential of the sustainable development goals (SDGs). International Environmental Agreements: Politics, Law and Economics, 16(3), 393-396.

Sustainable Development Knowledge Platform, 2018. Higher Education Sustainability Initiative https://sustainabledevelopment.un.org/sdinaction/hesi (accessed 22 August 2018).

UNESCO, 2014. Shaping the Future We Want: UN Decade of Education for Sustainable Development, Final Report, UNESCO Publishing: Paris.

United Nations, 2016. Global Sustainable Development Report, Department of Economic and Social Affairs, New York.

Velazquez, L., Munguia, N., Sanchez, M., 2005. Deterring sustainability in higher education institutions: An appraisal of the factors which influence sustainability in higher education institutions. International Journal of Sustainability in Higher Education, 6(4), 383-391.

Viebahn, P., 2002. An environmental management model for universities: from environmental guidelines to staff involvement. Journal of Cleaner Production, 10, 3-12.

WCED, 1987. Brundtland Report (1987). Our Common Future: Report of the World Commission on Environment and Development, United Nations. http://www.un-documents.net/wced-ocf (accessed 22 August 2018). 
Wemmenhove, R., de Groot, W.T., 2001. Principles for university curriculum greening. An empirical case study from Tanzania. International Journal of Sustainability in Higher Education, 2(3), 267-283. Wiek, A., Withycombe, L. Redman, C. L., 2011. Key competencies in sustainability: a reference framework for academic program development. Sustainability Science 6(2), 203-218.

Zilahy, G., Huisingh, D., 2009. The roles of academia in regional sustainability initiatives. Journal of Cleaner Production, 17(12), 1057-1066.

Zimm, C., Sperling, F., Busch, S., 2018. Identifying Sustainability and Knowledge Gaps in SocioEconomic Pathways Vis-à-Vis the Sustainable Development Goals. Economies, 6(2), 20.

\section{Appendix A}

A. Nature of your University: ( ) Public ( ) Private

B. City:

C. Country:

\section{Part 1- Networking}

1. How well would you consider your local network, i.e. your links on matters related to sustainable development with local organisations?
( ) Excellent
( ) Very good
( ) Good
( ) Rather weak
( ) Very weak

2. With which organisations do you usually cooperate on sustainable development issues? (multiple choices possible)

( ) Other universities ( ) Other educational institutions (e.g. schools)
( ) Businesses
( ) NGOs
( ) Others (please specify)

3. How frequently do you cooperate with local organisations on sustainable development issues?
( ) Very often
( ) Often
( ) Sometimes
( ) Seldom
( ) Hardly ever

4. For how long have you been cooperating on sustainable development issues, with local organisations?
( ) Over 10 years
( ) Between 5 and 10 years
( ) Between 3 to 4 years
( ) Between 1 and 2 years
( ) One year or less

5. What are the factors which hinder cooperation on sustainable development at the local level (multiple choices possible)?
( ) Lack of time
( ) Lack of coordination
( ) Lack of interest from my university/ my colleagues
( ) Lack of resources /incentives
( ) Lack of interest from local organisations
( ) Other (please specify)

\section{Part 2- Cooperation in Local Initiatives}


6. By means of which initiatives do you usually cooperate with local organisations? (multiple choices possible)

\begin{tabular}{|l|l|l|l|l|l|l|}
\hline & $\begin{array}{l}\text { Other } \\
\text { universities }\end{array}$ & $\begin{array}{l}\text { Other } \\
\text { educational } \\
\text { institutions }\end{array}$ & Businesses & NGOs & $\begin{array}{l}\text { Church } \\
\text { Religious } \\
\text { groups }\end{array}$ & Others \\
\hline $\begin{array}{l}\text { Support in organising/ } \\
\text { running sustainability } \\
\text { related events at your } \\
\text { university's premises }\end{array}$ & & & & & \\
\hline $\begin{array}{l}\text { Support in organising/ } \\
\text { running sustainability } \\
\text { related events outside your } \\
\text { university joint }\end{array}$ & & & & & & \\
\hline $\begin{array}{l}\text { Support in in } \\
\text { sustainability projects }\end{array}$ & & & & & & \\
\hline $\begin{array}{l}\text { Support } \\
\text { management/administration } \\
\text { tasks on sustainability }\end{array}$ & & & & & \\
\hline $\begin{array}{l}\text { Facilitating networking on } \\
\text { sustainability with other } \\
\text { organisations }\end{array}$ & & & & & & \\
\hline $\begin{array}{l}\text { Provisions of advice to local } \\
\text { initiatives }\end{array}$ & & & & & & \\
\hline $\begin{array}{l}\text { Testing new approaches or } \\
\text { methods useful to local } \\
\text { communities }\end{array}$ & & & & & & \\
\hline $\begin{array}{l}\text { Capacity-building to } \\
\text { members of the local } \\
\text { communities }\end{array}$ & & & & & & \\
\hline Others (please specify) & & & & & \\
\hline
\end{tabular}

7. Which thematic areas are usually part of your cooperation with local organisations? (multiple choices possible)

\begin{tabular}{|l|l|l|l|l|l|}
\hline & $\begin{array}{l}\text { Other } \\
\text { universities }\end{array}$ & $\begin{array}{l}\text { Other } \\
\text { educational } \\
\text { institutions }\end{array}$ & Businesses & NGOs & Others \\
\hline $\begin{array}{l}\text { Theory of sustainable } \\
\text { development }\end{array}$ & & & & & \\
\hline $\begin{array}{l}\text { Practice of sustainable } \\
\text { development }\end{array}$ & & & & & \\
\hline Nature-based learning & & & & & \\
\hline $\begin{array}{l}\text { The Sustainable } \\
\text { Development Goals }\end{array}$ & & & & & \\
\hline
\end{tabular}




\begin{tabular}{|l|l|l|l|l|l|}
\hline $\begin{array}{l}\text { Support on concrete } \\
\text { occasions/ case studies }\end{array}$ & & & & & \\
\hline Other (please specify) & & & & & \\
\hline
\end{tabular}

8. How satisfied are you with the results of the cooperation on sustainable development, achieved to date?

( ) Very satisfied

( ) Satisfied

( ) Some satisfaction

( ) Little satisfaction

( ) Not at all

\section{Part 3- Case studies}

9. Please provide two examples, as case studies, of your work with local organisations. Please state the partner, the nature of this cooperation, the activities held to date and their outputs.

Case study 1

Case study 2

10. In your opinion, what should be done to achieve a better relation and/or intensify cooperation efforts at the local level?

Please let us know if you have any other comment or wish to add anything. 